\title{
Clinical Use of Progestins and Their Mechanisms of Action: Present and Future (Review)
}

\author{
DOI: $10.17691 / \mathrm{stm} 2021.13 .1 .11$ \\ Received June 23, 2020 \\ T.A. Fedotcheva, MD, DSc, Senior Researcher, Research Laboratory of Molecular Pharmacology \\ Pirogov Russian National Research Medical University, 1 Ostrovitianova St., Moscow, 117997, Russia
}

This review summarizes the current opinions on the mechanisms of action of nuclear, mitochondrial, and membrane progesterone receptors. The main aspects of the pharmacological action of progestins have been studied. Data on the clinical use of gestagens by nosological groups are presented. Particular attention is paid to progesterone, megestrol acetate, medroxyprogesterone acetate due to broadening of their spectrum of action. The possibilities of using gestagens as neuroprotectors, immunomodulators, and chemosensitizers are considered.

Key words: progesterone; megestrol acetate; medroxyprogesterone acetate; gestagens; progesterone receptors.

How to cite: Fedotcheva T.A. Clinical use of progestins and their mechanisms of action: present and future (review). Sovremennye tehnologii v medicine 2021; 13(1): 93, https://doi.org/10.17691/stm2021.13.1.11

\section{Introduction}

Progesterone is a natural endogenous steroid sex hormone secreted by the ovaries. It interacts with its specific receptors in the reproductive tract, the mammary gland, and the central nervous system. Progesterone and progestins have been used for decades for contraception, maintenance of pregnancy with threatened miscarriage, for symptomatic therapy of postmenopause, secondary amenorrhea, abnormal uterine bleeding $[1,2]$. In the last 30 years, progestins have been used for treatment of endometriosis and hormone-sensitive tumors, and during the last 15 years - in ART (assisted reproductive technologies) procedures [3]. Clinical efficacy of some gestagens has been confirmed in management of cachexia and anorexia in cancer patients and AIDS patients [4]. Owing to the discovery of previously unknown targets for progestin action (membrane-associated progesterone receptors; xenobiotic transport proteins, mitochondrial pores; checkpoint signaling pathway proteins), new aspects of clinical use of progesterone and its synthetic analogues have emerged.

\section{Mechanism of progestin (gestagen) action}

The mechanism of progestin action is realized through nuclear, mitochondrial, and membrane progesterone receptors (Figure 1).

Nuclear progesterone receptors (nPR) are represented by isoforms $A$ and $B$ (nPR-A and $n P R-B)$, which are transcription products of one gene resulting from the action of different promoters. When gestagen binds to nuclear receptors (transcription factors), it is accompanied by genomic effects that develop over several hours and days, leading to specific physiological and morphological changes in target organs, which is the classic progestin action [5].

Progesterone also induces rapid (minutes, hours) stimulation of cellular signaling cascades through membrane progesterone receptors (mPR) and membrane-associated progesterone receptors (MAPR) which are two different types of membrane receptors [6].

Membrane receptors of the first type are adipoQ receptors (PAQR): mPRa (PAQR7), mPR (PAQR8), $\mathrm{mPR} \gamma$ (PAQR5) are associated with inhibitory G-proteins, they reduce the intracellular concentration of CAMP; mPR $\delta$ (PAQR6) and mPRE (PAQR9), on the contrary, increase cAMP [7]. Receptor mPRa is expressed mainly in the human reproductive organs, $\mathrm{mPR} \beta-$ in the central nervous system, while $\mathrm{mPR} \gamma$ - in the kidneys and intestines. The latest identified receptors MPR $\delta$ and $\mathrm{mPR} \varepsilon$ are still understudied, but their neuroprotective function and localization in the central nervous system are already obvious. For example, brain biopsies from men and women who died unexpectedly at the age of 1665 years showed that $\mathrm{mPR} \delta$ and $\mathrm{mPR} \varepsilon$ were present in all brain structures; in high-affinity cell models, they bind neurosteroids dehydroepiandrosterone, pregnanolone, pregnenolone, allopregnanolone and produce their anti-apoptotic effect [8].

Membrane receptors of the second type are members of b5-like heme/steroid-binding protein family: the membrane component of the $1^{\text {st }}$ and $2^{\text {nd }}$ progesterone receptors (PGRMC1 and PGRMC2); neudesin

Corresponding author: Tatyana A. Fedotcheva, e-mail: tfedotcheva@mail.ru 


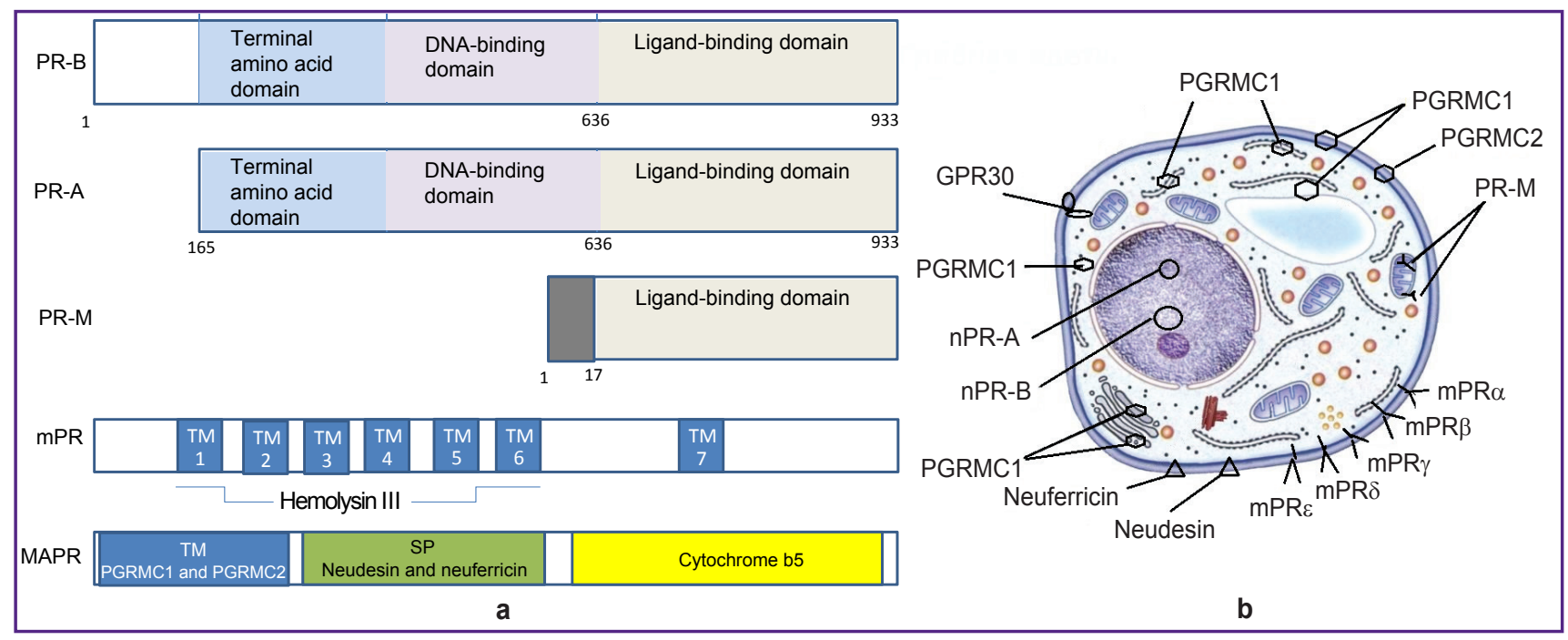

Figure 1. Structure and localization of progesterone receptors:

(a) protein domains of nuclear (nPR-A, nPR-B), mitochondrial (PR-M), membrane (mPR) and membrane-associated progesterone receptors (MAPR); (b) localization of progesterone receptors in the cell: nPR-A and nPR-B are localized in the nucleus, PGRMC1 - in the cell membrane, endoplasmic reticulum, the Golgi apparatus, in the cytoplasm, PR-M — in mitochondria, other membrane receptors and MAPR — in the cell membrane. Here: TM — transmembrane domain in PGRMC1 and PGRMC2; SP — signal peptide in neudesin and neuferricin; GPR30 — G-protein-coupled receptor

neurotrophic factor (NENF) and neuferricin (CYP5D2) with transmembrane localization [9]. They are found in the forebrain structures where progesterone is responsible for neuroendocrine regulation and other non-genomic effects: membrane transport, steroidogenesis, iron homeostasis, and heme transport due to regulation of hepcidin expression and ferrochelatase activity, lipid transport, migration of nerve axons, synaptic function, and antiapoptotic action. PGRMC1 has been studied best of all as a multifunctional protein with a heme-binding site, providing transfer of partner proteins (estradiol receptors, growth factors, cytochromes) from intracellular depots to the point of meeting with a specific ligand [5]. Localization of PGRMC1 can be cytoplasmic, nuclear/nucleolar, mitochondrial, in the endoplasmic reticulum, in cytoplasmic vesicles, or extracellular (Figure 1 (a)). PGRMC1 is involved in cell cycle processes at the $\mathrm{G} 1$ checkpoint during mitosis, while overexpression of PGRMC1 is associated with adverse prognosis in many types of cancer [10]. PGRMC2 is structurally similar to PGRMC1, although there are differences in the $\mathrm{N}$-terminal transmembrane domain. PGRMC2 is not well understood, but it is known to participate in cell cycle processes and to inhibit cell migration during tumor invasion [9]. Neudesin exhibits neurotrophic activity by heme binding, which is then mediated by mitogen-activated protein (MAP) and phosphatidylinositol-3-kinase (PI3K). Neuferricin (cytochrome b5 domain) was discovered via a homology-based search of the CYB5-like heme/steroid-binding domain of neudesin. A rare human condition of cytochrome b5 deficiency causes disorders of sexual development and appearance of hermaphroditism signs [11].

The latest discovered non-nuclear progesterone receptor is mitochondrial progesterone receptor (PR-M). It is a truncated version of $\mathrm{nPR}$ localized in mitochondria (Figure 1 (b)) [12]. It is involved in direct ligand-dependent regulation of mitochondrial functions; increased production of cellular energy when needed - for example, during pregnancy. Investigation of the role of the mitochondrial receptor in various cellular processes is just beginning. There are many assumptions concerning its functions increased proliferation and viability of lobular-alveolar cells of the mammary gland and myometrial cells, increased synthesis of myofibrils in the myocardium and myometrium. It is also necessary to consider the role it plays in increasing the rate of cellular metabolism by inducing ATP production in mitochondria [6]. Progesterone-dependent increase in basal body temperature has traditionally been associated with its major influence on the hypothalamus, but identification of PR-M casts doubt on this fact.

Non-classical mPR and MAPR are believed to evolve first in the ancient bilateria, while classical nuclear progesterone receptors appeared later in vertebrates [13].

\section{Pharmacological action of gestagens}

The main pharmacological effects of progesterone, exerted mainly by nuclear receptors, are the following:

endometrial secretory transformation;

formation of thick and viscous cervical mucus; 
increased basal temperature;

reduced activity of genital tract and uterine smooth muscles (tocolytic effect);

activation of mammary gland secretory acini growth

and induction of lactation;

protein lipase stimulation;

increased fat stores;

basal and induced insulin levels and glucose

utilization rate;

liver glycogen accumulation;

aldosterone production;

hypoazotemia and azoturia;

increased (in small doses) or suppressed (in large doses) gonadotropic hormone production in the pituitary gland.

Pharmacological effects of progestins (progesterone analogues) are usually assessed during a number of preclinical studies in animals, namely:

determination of affinity for progesterone receptors;

assessment of gestagenic activity using endometrial transformation test, pregnancy maintenance test, and ovulation inhibition test;

assessment of androgenic activity by measuring the weight of the prostate or levator ani muscle;

measuring anti-androgenic activity or evaluating feminizing activity in male rats;

analysis of glucocorticoid and antimineralocorticoid properties [14].

The most important structural and functional role in the mechanism of gestagen action is played by substituents at the carbon atoms $\mathrm{C} 3$ and $\mathrm{C} 17$ of the cyclopentaneperhydrophenanthrene ring - the steroid nucleus. It is well known that even small structural differences in steroid molecules cause significant differences in their clinical effects on target organs and on the risk of developing cardiovascular diseases. Specifically, natural progesterone and some of its derivatives, for example, drospirenone, have potent anti-mineralocorticoid activity and a beneficial effect on blood pressure; dienogest has no androgenic effect and, therefore, no negative influence on lipid and carbohydrate metabolism and directly on endothelial cells. Investigation on mice fed a diet high in fat and drospirenone showed no increase in body weight or adipose tissue mass or changes in the level of glucose tolerance due to drospirenone antagonism to mineralocorticoid receptors controlling adipocyte function [15]. Gestagens lacking a keto group at the C3 carbon atom (mepregenol derivatives Acetomepregenol, gestobutanoil) are unable to bind to androgenic and mineralocorticoid receptors, therefore they produce no side mineralocorticoid, androgenic, virilization effects [16, 17].

\section{Clinical use of gestagens}

The dosage forms of gestagens existing in the Russian pharmaceutical market and indications for their use are presented in the Table.
Gestagens are successfully used for contraception, pregnancy maintenance, and secondary amenorrhea. They are the front-line therapy for endometrial hyperplasia and cancer [18-20]. Gestagens are used in hormone replacement therapy (HRT) to prevent osteoporosis and in ART procedures [21].

A new aspect of clinical use of gestagens is treatment of cachexia and anorexia with megestrol acetate. It promotes weight gain, increased appetite, but the mechanism of this effect remains unclear [22]. The effect of megestrol acetate on anorexia and weight gain might be associated with inhibition of pro-inflammatory cytokine production (IL-1, IL-6, various TNFs) and stimulation of the hypothalamus with neuropeptide $Y$ [23]. In 1993, the Food and Drug Administration (FDA) approved its use for treatment of anorexia, cachexia, or unexplained weight loss in patients with acquired immunodeficiency syndrome (AIDS). The advantage of this gestagen is the absence of general toxic, mutagenic or carcinogenic properties. Therefore, treatment of endometrial cancer with Megace based on megestrol acetate allows young patients to maintain reproductive function [24].

The main aspects of clinical use of progestins and their mechanism of action are shown in Figure 2.

\section{Gestagens in contraception and pregnancy maintenance}

Progesterone plays an important role in the onset and development of pregnancy ("pregnancy hormone") due to various mechanisms. They include modulation of the mother's immune response and suppression of the inflammatory response, reduction of uterine contractility (adequate progesterone concentrations in the myometrium can counteract the stimulating activity of prostaglandin and oxytocin), improvement of blood circulation in the uteroplacental system and luteal phase support (progesterone promotes penetration of extravillous trophoblasts into decidual cells by inhibiting apoptosis of these trophoblasts [25].

In the 50-80s of the last century, the main indication for administration of progestins was pregnancy maintenance. Today, the gold standard is the use of dydrogesterone (Duphaston) and progesterone (Utrogestan), their efficacy has been proven by many clinical studies [26-30].

Later, contraceptives based on gestagens appeared in the pharmaceutical market. The greatest variety of trade names and dosage forms has been created specifically for these purposes. Millions of women use combined oral contraceptives (COCs) because they are highly effective in preventing pregnancy. However, COCs appear to be unsuitable for some women because of cardiovascular risks associated with their use. In addition, they are capable of producing side effects due to the presence of estrogens in their composition: headache, nausea, weight gain, breast tension, and others. 


\section{REVIEWS}

\section{Dosage forms and indications for the use of progestins in Russia}

\begin{tabular}{|c|c|c|c|}
\hline ICD-10/Nosology & Gestagen & Trade name & Dosage form \\
\hline \multirow{5}{*}{$\begin{array}{l}\text { O20.0 } \\
\text { Threatened abortion }\end{array}$} & Dydrogesterone & Duphaston $®$ & Tablets, 10 mg \\
\hline & Micronized progesterone & Utrogestan® & Capsules, 100 and $200 \mathrm{mg}$ \\
\hline & Hydroxyprogesterone caproate & Oxyprogesterone capronate $\AA$ & Solution for injection in oil $12.5 \%$ in ampoules \\
\hline & Allylestrenol & Turina/® & Tablets, 5 mg \\
\hline & Acetomepregenol & Acetomepregeno/囚 & Tablets, $0.5 \mathrm{mg}$ \\
\hline \multirow{14}{*}{$\begin{array}{l}Z 30 \\
\text { Monitoring the use } \\
\text { of contraceptives }\end{array}$} & Desogestrel & Lactinette $§$ & Tablets, $0.075 \mathrm{mg}$ \\
\hline & Desogestrel & MODELLE® MAM & Tablets, $0.075 \mathrm{mg}$ \\
\hline & Levonorgestrel & Microlut $囚$ & Tablets, $0.03 \mathrm{mg}$ \\
\hline & Levonorgestrel & Mirena® & Intrauterine therapy system with guide, $52 \mathrm{mg}$ \\
\hline & Levonorgestrel & MODELLE® 911 & Tablets, $1.5 \mathrm{mg}$ \\
\hline & Levonorgestrel & Norplant $₫$ & $\begin{array}{l}\text { Subcutaneous implantable capsules containing } \\
36 \mathrm{mg} \text { of levonorgestrel }\end{array}$ \\
\hline & Levonorgestrel & Postinor@ & Tablets, $0.75 \mathrm{mg}$ \\
\hline & Levonorgestrel & Escapelle® & Tablets, $1.5 \mathrm{mg}$ \\
\hline & Levonorgestrel & Eskinor-F & Tablets, $0.75 \mathrm{mg}$ \\
\hline & Lynestrenol & Exluton® & Tablets, $0.5 \mathrm{mg}$ \\
\hline & Lynestrenol & Orgametri| & Tablets, $5 \mathrm{mg}$ \\
\hline & Acetomepregenol & 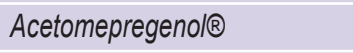 & Tablets, $0.5 \mathrm{mg}$ \\
\hline & Norethisterone & Norkolut@ & Tablets, $5 \mathrm{mg}$ \\
\hline & Etonogestrel & Implanon NXT® & Implant, 68 mg \\
\hline $\begin{array}{l}\text { N91 } \\
\text { Suppressed menstruation, } \\
\text { scanty and infrequent } \\
\text { menstruation } \\
\text { N91.1 } \\
\text { Secondary amenorrhea }\end{array}$ & Progesterone & Krinon® & Vaginal gel, 90 mg/dose, 15 pcs. \\
\hline \multirow{4}{*}{$\begin{array}{l}\mathrm{N} 80.0 \\
\text { Endometriosis }\end{array}$} & Dydrogesterone & Duphaston® & Tablets, $10 \mathrm{mg}$ \\
\hline & Dienogest & Visanne® & Tablets, 2 mg \\
\hline & Norethisterone & Norkolut $@$ & Tablets, $5 \mathrm{mg}$ \\
\hline & Norethisterone & Primolut@-Nor & Tablets, 5 and $10 \mathrm{mg}$ \\
\hline $\begin{array}{l}\text { N85.0 } \\
\text { Glandular endometrial } \\
\text { hyperplasia }\end{array}$ & Levonorgestrel & Mirena® & Intrauterine therapy system with guide, $52 \mathrm{mg}$ \\
\hline \multirow{3}{*}{$\begin{array}{l}\text { C54 } \\
\text { Malignant neoplasm } \\
\text { of the uterine body }\end{array}$} & Gestonorone caproate & Depostat ( & $\begin{array}{l}1 \mathrm{ml} \text { oil solution for injection containing } \\
100 \mathrm{mg} \text { of Gestonorone caproate }\end{array}$ \\
\hline & Hydroxyprogesterone caproate & Oxyprogesterone capronate $®$ & Solution for injection in oil $12.5 \%$ in ampoules \\
\hline & Linestrenol & Orgametril ( & Tablets, $5 \mathrm{mg}$ \\
\hline \multirow{2}{*}{$\begin{array}{l}\text { C50 } \\
\text { Malignant neoplasm } \\
\text { of breast }\end{array}$} & Gestonorone caproate & Depostat $($ & $\begin{array}{l}1 \mathrm{ml} \text { oil solution for injection containing } 100 \mathrm{mg} \\
\text { of Gestonorone caproate }\end{array}$ \\
\hline & Medroxyprogesterone & Provera $®$ & Tablets, 100 and $500 \mathrm{mg}$ \\
\hline $\begin{array}{l}\text { C53 } \\
\text { Malignant cervical neoplasm }\end{array}$ & Hydroxyprogesterone caproate & Oxyprogesterone capronate $®$ & Solution in oil $12.5 \%$ in ampoules \\
\hline $\begin{array}{l}\text { C54.1 } \\
\text { Malignant endometrial } \\
\text { neoplasm }\end{array}$ & Medroxyprogesterone & Provera $®$ & Tablets, 100 and $500 \mathrm{mg}$ \\
\hline \multirow{2}{*}{$\begin{array}{l}Z 31.1 \\
\text { Assisted reproductive } \\
\text { technologies }\end{array}$} & Progesterone & Krinon® & Vaginal gel, 90 mg/dose, 15 pcs. \\
\hline & Progesterone & Utrogestan® & Capsules, 100 and $200 \mathrm{mg}$ \\
\hline
\end{tabular}

N o t e: italics indicate drugs temporarily absent on the Russian pharmaceutical market. 


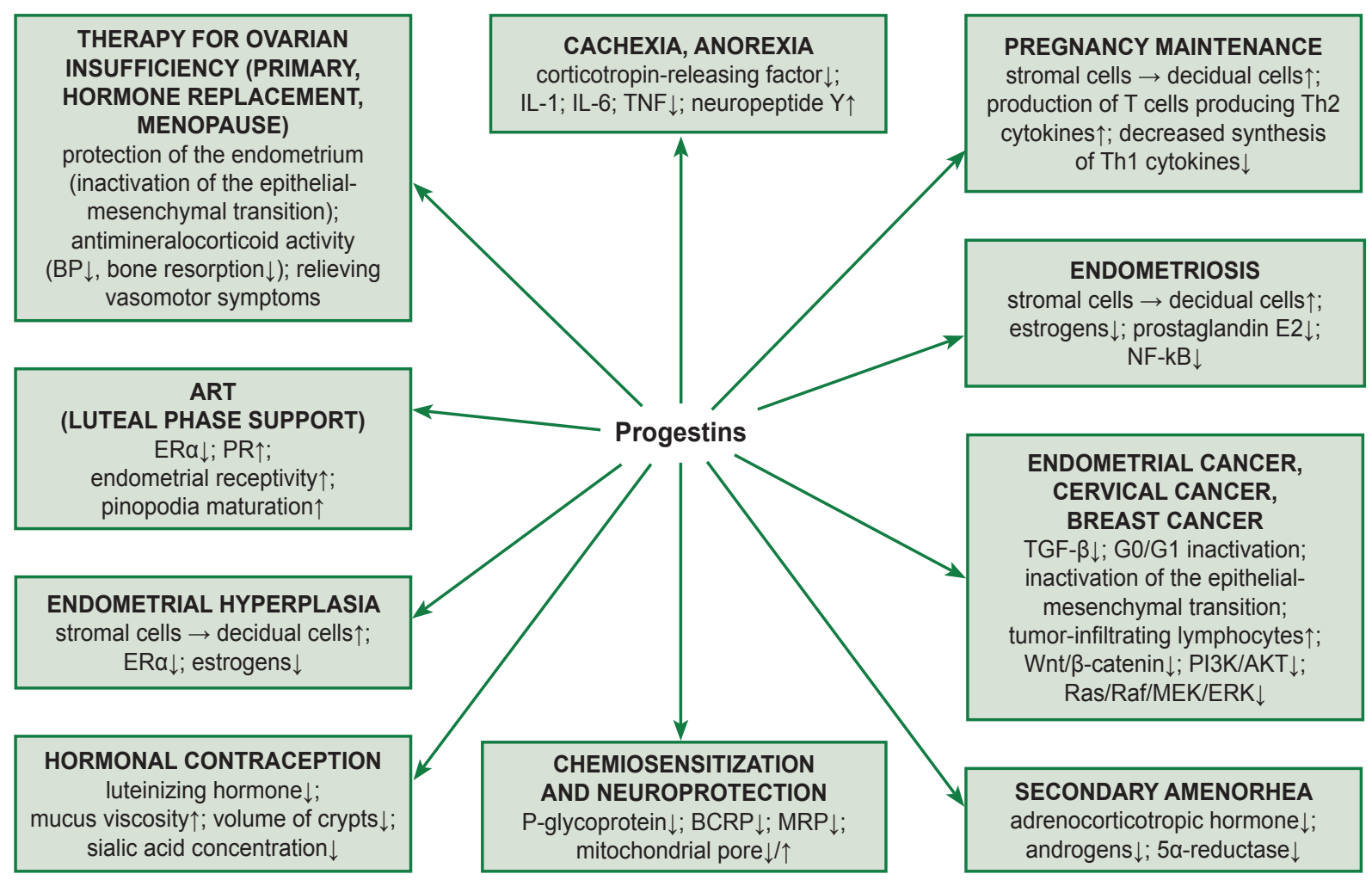

Figure 2. The main aspects of clinical use of gestagens with the mechanism of action

Unlike the widely used COCs, there are progestogen-only pills taken continuously without any breaks between packets (mini-pills) and various devices - coils and patches producing small amounts of gestagen daily. Progestagen-only formulations (progestin-only contraceptives - POCs) are an acceptable option for women in whom estrogens are contraindicated. Among the variety of mini-pills in the US pharmaceutical market, there are POCs containing norethindrone, while tablets with levonorgestrel or desogestrel are available on the international pharmaceutical market [31]. The drug Lactinette based on desogestrel is the leader of mini-pills market in the Russian Federation.

The contraceptive action of progestins is mediated through the following mechanisms [32]:

1. Inhibiting effect on the secretion of gonadotropic hormones by the pituitary gland (especially luteinizing hormone) and, as a consequence, inhibition of ovulation (depends on the dose of gestagen in the tablet).

2. Increased viscosity of cervical mucus. Progestins reduce crypt volume, thicken cervical mucus, reduce sialic acid content in the mucus and sperm activity, they narrow the cervical canal, thereby preventing penetration of sperm and some microorganisms into the cervical canal, uterus, and fallopian tubes.

3. Specific effect on the endometrium. Progestins suppress mitotic activity of the endometrium, promoting its premature secretory transformation. Long-term use of progestagens under conditions of anovulation causes hypotrophy and atrophy of the endometrium, which prevents implantation of the fertilized ovum.

4. Decrease in the contractile activity of the fallopian tubes by reducing the contractility and excitability threshold of smooth muscle cells of their walls.

One of the latest developments is Implanon NXT, a long-acting (3 years) subcutaneous radiopaque hormonal contraceptive with etonogestrel $[33,34]$. It is distinguished by a rapid onset of action and a rapid return of fertility after withdrawal, the absence of mineralocorticoid activity. This drug is easy to use, its efficacy does not depend on the correct use, which is very important, because unplanned pregnancy often occurs due to inappropriate usage of contraceptives [35, 36].

In recent years, there has been a tendency towards an increase in the number of women who have made their choice in favor of LARC-methods of contraception (long-acting reversible contraception) [37, 38].

\section{Endometriosis}

Success of the disease treatment depends on individually selected drug therapy based on the molecular genetic characterization of the patient's endometrioid tissue [39]. The main molecular mechanisms of gestagen action on the pathogenetic components of endometriosis are as follows: 1) gestagens inactivate the hypothalamic-pituitary-ovarian axis of estrogen synthesis; 2) competitively bind to estrogen 
receptors, providing an anti-estrogenic effect; 3 ) inhibit prostaglandin $\mathrm{E}_{2}$ synthesis; 4) inhibit the enzyme aromatase (CYP19); 5) activate the HSD17B2 enzyme; 6) cause direct inhibition of nuclear factorkappa B (NF-kB) playing a key role in the processes of inflammation and neoangiogenesis; 7) have a direct effect on endometriotic foci, causing differentiation of stromal cells (decidualization) and secretory transformation of endometrial epithelial cells, which results in endometrial atrophy.

Currently, only three gestagens are recommended for the treatment of endometriosis: medroxyprogesterone acetate (MPA), dienogest, and dydrogesterone. Of these drugs, only dienogest has direct indications for the treatment of endometriosis in Russia; in other countries, both MPA and dydrogesterone are used [16, 40, 41].

There is a novel domestic development at the stage of clinical trials - gestagen gestobutanoil in tablet dosage form, which is equal to foreign dienogest in efficacy. It was revealed on experimental models of endometriosis that the drug has two metabolites, one of which is megestrol acetate circulating in the blood for a long time. This property of the drug can ensure its prolonged gestagenic action [17, 42-46].

\section{Endometrial hyperplasia}

Endometrial hyperplasia $(E H)$ is defined by some authors as morphological and biological changes in the endometrium resulting from prolonged stimulation with estrogens against the background of progesterone deficiency [47]. EH is a precancerous condition of the endometrium. Cytological atypia with expression of such markers as pyruvate kinase $M 2, \beta$-catechin, and the presence of MELF (microcystic, elongated, fragmented glands) regions [48-50] seem to be the most important factors in transformation of hyperplasia into carcinoma. The main goal in treating women with $\mathrm{EH}$ is not only to reduce the frequency and intensity of abnormal uterine bleeding, but also to prevent the endometrium from transformation into a tumor. The mechanism of the protective effect of progestins on the endometrium lies in the fact that they transfer the endometrium from the proliferative phase to the secretory phase, causing the so-called secretory transformation of the endometrium. The second mechanism is anti-estrogenic, i.e. there is a decrease in the mitotic effect of estrogens on the endometrium (see Figure 2).

Levonorgestrel in the form of the Mirena intrauterine system is recommended as the front-line drug therapy in Russia and abroad [51]. Levonorgestrel does not reduce the volume of the ovaries and ovarian reserve and, compared to COCs, slightly reduces the concentration of anti-Müllerian hormone [52], which allows young women with $\mathrm{EH}$ to maintain reproductive function.

The most important strategy in the treatment of $\mathrm{EH}$ is controlling the potential of endometrial malignancy, therefore it is necessary to perform regular immunohistochemical studies, in particular, to determine such markers as PTEN, p53, $\beta$-catechin, Bcl-2, COX-2, p27, p21, MLH-1, -2 and -6 , survivin, p16, and also expression of estrogen and progesterone receptors (ER- $\alpha$, ER- $\beta, n$ PR-A, nPR-B) [53].

\section{Endometrial cancer and cervical cancer}

Endometrial cancer (EC) is the most common type of neoplasm in gynecology; every year it is detected with increasing frequency [54]. The use of COCs is considered to be a protective, prophylactic factor reducing the risk of EC development, the residual protective effect lasting up to 30 years after discontinuation of the drug [55].

The first-line drug therapy for EC is the use of classical cytostatics (doxorubicin, cisplatin, paclitaxel, and others) and hormone therapy (MPA, megestrol acetate, tamoxifen) [56]. Treatment with progestins is quite effective: the response rate ranges from 11 to $56 \%$, depending on EC type (the greatest efficacy is achieved with endometrioid EC (type I)). Targeted therapy for EC leads to no good results: as evidenced by the analysis of clinical studies, the response rate does not exceed 33\% with the use of various drugs [54].

Clinical studies have repeatedly confirmed MPA efficacy in EC treatment, especially as neoadjuvant therapy [57-59]. MPA activates estrogen stress, blocks signal transduction from the estrogen receptor by binding to $\mathrm{nPR}-\mathrm{B}$, and increases expression of the enhancer protein $\mathrm{CHOP}$, which might be one of the molecular mechanisms underlying the antitumor effect of MPA in EC. In cells containing nPR-B (nPR-B+), long non-coding RNAs (IncRNAs), Inc-CETP-3, are involved in this process. Recently, there have been identified differentially expressed mRNAs and IncRNAs involved in signaling cascades of carcinogenesis, which can become a target for anticancer drugs and, in particular, for gestagens [60].

The optimal regimen for the use of gestagens in EC is daily oral intake of $200-400 \mathrm{mg}$ of MPA (Provera) or $160 \mathrm{mg}$ of megestrol acetate (Megace). The effect of progestin therapy begins to manifest itself no earlier than 8-12 weeks after the start date of drug administration [61].

The use of gestagens in breast cancer and cervical cancer (CC) is limited because there is insufficient information about their effects on these types of cancer. Interim results of a large (1000 patients) clinical trial, Primary Progesterone Therapy for Operable Breast Cancer, show that progesterone therapy significantly increases relapse-free survival in patients with lymph node involvement, but does not affect this parameter in patients with primary breast cancer without lymph node involvement [62].

Despite the fact that hydroxyprogesterone caproate has indications for the treatment of $\mathrm{CC}$, according to ICD-10 C53 "Malignant Cervical Neoplasm", 
hormone therapy is currently not recommended for treatment of this disease in the Russian Federation [63]. Hormone therapy is not used by the European communities of oncologists either [64]. However, a $0.25 \%$ solution of oxyprogesterone capronate (17-OPC) is recommended according to an individual therapeutic regimen only in glandular forms of $\mathrm{CC}$.

The mechanism of the cytotoxic action of progesterone (and its analogues) consists of inducing the mitochondrial apoptosis and preventing cell cycle transition from the $\mathrm{G} 1$ to $S$ phase [65]. It has been confirmed that regulation of expression and activity of the transient receptor potential melastatin-subfamily member 7 (TRPM7), which triggers acidotoxic necrosis in CC cells, plays the role in the direct cytotoxic effect of progesterone. Progesterone inhibits TRPM7 expression, thereby switching acidotoxic necrosis of tumor cells to apoptosis [66]. A number of studies on HeLa cells have demonstrated the cytotoxic effect not only of progesterone, but also of its synthetic derivatives, the cytotoxic effect being observed both upon stimulation with estradiol and without stimulation $[67,68]$.

The challenges of using gestagens in EC are associated with improvement of administration regimens based on the individual status of the patient and inclusion of other drugs, in particular metformin, in the treatment regimens. The antitumor mechanism of metformin action is poorly understood, but it appears to be related to the mTOR signaling pathway. Metformin is a biguanide widely used in the treatment of type 2 diabetes. Analysis of several recent epidemiological studies [19, 69, 70] has shown that metformin reduces the risk of cancer development and mortality in diabetic patients with endometrial hyperplasia and carcinoma.

Since the incidence of EC in young patients often correlates with obesity, insulin resistance, and impaired glucose metabolism $(84,83$, and $78 \%$, respectively), these provoking factors are a promising target for treatment and prevention of this disease with metformin [71-73].

\section{Hormone replacement therapy}

The role of gestagens in HRT mainly involves protecting the endometrium from malignization, exerting antimineralcorticoid action, preventing osteoporosis, and relieving psychoemotional and vasomotor symptoms [74].

Professor Jerilynn C. Prior of the University of British Columbia (Vancouver, Canada) is an expert in clinical research on progesterone in HRT. She found that in HRT progesterone effectively reduces vasomotor symptoms in perimenopausal women, prevents osteoporosis, normalizes sleep, and eliminates anxiety [75]. The beneficial effect of progesterone on physiological functions, psychoemotional state, and life expectancy has been shown even in transgender women [76].

Besides, progestins are effective in treatment of secondary amenorrhea: vaginal progesterone Crainon gel — is the drug of choice [77].

\section{Assisted reproductive technologies}

Assisted reproductive technologies are increasingly used in modern medicine. The protocols of in vitro fertilization (IVF), artificial insemination, and transfer of cryo-preserved embryo transfer are constantly being improved as evidenced by a number of initiated and completed clinical studies [78, 79].

Most ART cycles are accompanied by formation of luteal phase insufficiency. Therefore, gestagen drugs are widely used in infertile women during ART when superovulation is stimulated or cryo-preserved embryo transfer program requiring gestagen therapy is performed [80]. Progesterone reduces ER- $\alpha$ levels, increases expression of progesterone receptors, thereby increasing sensitivity of the endometrium to progesterone and endometrial receptivity. In contrast to the proliferative effect of estrogen, progesterone action promotes differentiation of endometrial tissue inactivating estradiol through stromal progesterone receptors, emergence and maturation of pinopodia, ensures preparation of the endometrium for embryo implantation [81]. Progestins increase not only endometrial receptivity but also its thickness, which is an important factor in ensuring successful embryo implantation [82, 83].

Thus, ART is a relatively new nosological group for the clinical use of gestagens and its efficacy in improving fertility is uncontroversial.

\section{Non-classical pharmacological effects of progestins - a platform for new clinical trials}

The future of using gestagens in clinical practice is determined by the discovery of new targets for progesterone action on the immune system, the cardiovascular system, the central nervous system, and its specific, unique effect on drug metabolism, involving cytochrome systems, enzymes, and drug resistance proteins such as P-glycoprotein, BCRP protein, MRP proteins, and others.

Immunomodulatory effects of progestins are mainly associated with suppression of excessive immune response: inhibition of lymphocyte activation and proliferation in response to mitogenic and immune stimuli, which plays an important role in pregnancy maintenance as cytokine-mediated immunological reactions cause $40-60 \%$ of all recurrent idiopathic spontaneous miscarriages.

It has been recently revealed that maternal immune tolerance towards the fetus is a key factor contributing to its development. Successfully progressing pregnancy is accompanied by suppressed activity of type 1 T-helpers (Th1) and increased Th2 activity. For instance, increased levels of Th1-cytokines, IL-2, and interferon- $\gamma$ 
and decreased levels of Th2-cytokines and IL-10 were observed in women with recurrent spontaneous miscarriage [84].

Expression of cytokines and chemokines IL-6, IL-8, CCL2, CXCL1, CXCL2 in endothelial cells is specifically inhibited by progesterone, which indicates that progestins are anti-inflammatory agents in the endothelium with the potential to suppress the transport of immune cells into tissues [85]. The anti-inflammatory effect of progesterone was confirmed in the study by VanLandingham et al. Progesterone stimulates expression of membrane protein CD55 in the rat brain, a potent inhibitor of the complement system convertases, leading to inflammatory cascade inhibition [86].

Specific regulation of cytokine synthesis by progesterone might prove crucial in suppressing the cytokine storm in sepsis and viral diseases such as COVID-19. One of the main reasons for the death of patients infected with the SARS-CoV-2 coronavirus is the development of excessive immune response, a cytokine storm, leading to severe damage to vital organs. Pharmacological correction of the cytokine storm in severe forms of COVID-19 will likely save lives of the infected patients and achieve stabilization and improvement in patient conditions.

The drugs proposed for pharmacological correction of the cytokine storm during SARS-CoV-2 infection are glucocorticoids known for their prominent anti-inflammatory activity. However, their simultaneous strong immunosuppressive effect may limit the use of glucocorticoids [87]. Other drugs used for this purpose (the antimalarial agent hydroxychloroquinone and the cytostatic antitumor agent etoposide) also have serious toxic side effects [88, 89].

Hence, it seems appropriate to estimate the possibilities of gestagen derivatives (they are well tolerated and act as selective immunomodulators) for the immune correction of the cytokine storm. It has been shown that some progesterone derivatives possess prominent anti-inflammatory and immunomodulatory activity due to their unique action associated with inhibition of mitochondrial proton pumps, regulation of intracellular $\mathrm{pH}$, lysosomal enzyme activity, toll-like receptors of immune cells, and others [90-92].

Neuroprotective effects of progestins. Progesterone is also a neurosteroid synthesized in neurons and glial cells. Progesterone metabolites - 5a-dihydroprogesterone and $3 \alpha$, $5 \alpha$-tetrahydroprogesterone (allopregnanolone) have a neuroprotective effect in traumatic brain injury; spinal cord injuries; in ischemic damage to the brain and spinal cord; in neurodegenerative diseases, including cerebral atherosclerosis, Parkinson's and Alzheimer's disease. Progesterone reduces cerebral edema, inflammation, pro-oxidant activity of metabolites, restores mitochondrial membrane potential, regulates hemostatic proteins and promotes survival of newly formed neurons, participates in maturation and myelination of neurons. Allopregnanolone is $\mathrm{GABA}_{A}$ receptor positive allosteric modulator (gamma-aminobutyric acid receptors are chloride ion channels). As a result, progesterone and allopregnanolone affect synergistically many functions in the brain via progestin and $\mathrm{GABA}_{\mathrm{A}}$ receptors [93].

The human central nervous system was found to have all five types of membrane receptors with some differences in the level of their expression and distribution, as well as MAPR - PGRMC1, PGRMC2, neudesin, and neuferricin. Their functions are not well defined, but there is evidence that they are involved in the synthesis and transfer of heme, suppression of induced cell death, and apoptosis in cells [9].

Other important functions of progesterone in the central nervous system are modulation of the activity of neurons secreting gonadotropin-releasing factor, regulation of luteinizing hormone secretion, and regulation of monoamine (dopamine and serotonin) metabolism [94].

The effect of gestagens on carcinogenesis is associated with proliferation, apoptosis, and epithelial-mesenchymal transition of EC, breast cancer, $\mathrm{CC}$ in tumor cells. The main mechanisms of antitumor activity of gestagens are determined by a decrease in progesterone receptors nPR-A and estrogenic ER- $\beta$, induction of apoptosis by stimulating production of reactive oxygen species in high doses [95]. Megestrol acetate and MPA in high doses also have a direct receptor-mediated cytotoxic effect on tumor cells, in low doses, they reduce estrogen secretion and synthesis, reduce production of growth hormones, and increase production of tumor necrosis factors. Induction of the Fas/FasL system components by progesterone increases sensitivity of target cells to apoptotic signals. Progesterone can act as a regulator of alternative splicing of TGF- $\beta$ receptor gene. Besides, progestins regulate the activity of target cell enzymes involved in transmission of cell death signal, modulating cell response to the apoptotic signal [96].

Progesterone and its synthetic analogs can trigger the mitochondrial pathway of apoptosis. Mitochondrial membrane potential drop leads to formation of reactive oxygen species and release of apoptogenic factors (release of cytochrome $\mathrm{C}$ and activation of caspases), serving as a signal for activation of the final (effector) stage of apoptosis. Existing models of mitochondrial implementation of the apoptotic program take into account activity of regulatory protein family Bcl-2, disrupting mitochondrial homeostasis independently or through other mitochondrial proteins (adenine nucleotide carriers (ANT), voltage-dependent anion channels (VDAC)) [95]. It has been established that steroid hormones, in particular progesterone, produce extragenomic effects on mitochondrial processes aimed at inducing apoptosis due to the influence on ionic fluxes $\mathrm{Ca}^{2+}$ and $\mathrm{K}^{+}$, on the one hand, and expression of mitochondrial apoptosis-inducing factors (family 
$\mathrm{Bcl}-2$ ) on the other hand [97]. Our latest data point to the existence of membrane progesterone receptors whose localization, including that on the mitochondrial membrane, can determine the effect of gestagens on the transcription of mitochondrial genes and metabolic processes in mitochondria [98].

Progesterone is involved in regulation of four major signaling pathways for carcinogenesis: PI3K/AKT, Ras/ Raf/MEK/ERK, WNT/ $\beta$-catenin, and VEGF. The PI3K/ AKT pathway activates the transforming growth factor beta (TGF- $\beta$ )-mediated endothelial-to-mesenchymal transition (EMT). Progesterone inhibits EMT partly owing to its inhibitory effect on TGF- $\beta$. In vitro, progesterone inhibits TGF- $\beta$ signaling $72 \mathrm{~h}$ after treatment of Ishikawa endometrial cancer cells and effectively suppresses the viability and invasion of endometrial cancer cells with increased E-cadherin expression [99].

In addition to inhibiting EMT, progesterone stimulates immune protection, increasing production of tumor-infiltrating lymphocytes (TIL) [100]. Besides, the antitumor effect of progesterone is provided through its regulatory action on the so-called long non-coding RNA, NEAT1/microRNA-146b-5p, which mediates the WNT/B-catenin signaling pathway [101]. It was shown that incubation with $20 \mu \mathrm{M}$ progesterone significantly decreased expression level of the NEAT1, miR-146b-5p, LEF1, c-myc, and MMP9 genes of the WNT/ $\beta$-catenin signaling pathway in Ishikawa endometrial cancer cells, while the cell cycle was inhibited in the G0/G1 phase [101].

Another aspect of the possible clinical use of gestagens in oncology is their application as chemosensitizers of tumor cells, i.e. compounds increasing sensitivity of tumor cells to chemotherapy. Tumor cell resistance to the drugs used - the phenomenon of multiple drug resistance (MDR) - is known to be a significant limitation of anticancer therapy efficacy [102]. MDR is caused by overexpression of P-glycoprotein, multidrug resistance proteins (MRP), breast cancer resistance protein (BCRP), and other transmembrane transporters.

Four generations of P-glycoprotein inhibitors have been developed over the last 40 years; however, all these compounds have shown insufficient efficacy and high toxicity in clinical trials $[103,104]$.

Progesterone is an effective MDR modulator as most of the abovementioned transporter proteins have a specific progesterone-binding site [102]. It is known that progesterone regulates both the expression of P-glycoprotein mRNA and its protein levels [105], reduces BCRP-mediated MDR by suppressing BCRP expression in breast cancer cells, inhibiting transcription by binding to the progesterone promoter in the gene encoding BCRP [106]. It was shown in our paper that, in addition to their own cytostatic action on tumor cells, MPA, progesterone, and gestobutanoil gestagens exhibit chemosensitizing activity, increasing cytotoxic effects of cisplatin and etoposide by $20-50 \%$, therefore, they can be used in combination with cytostatics at the first stages of chemotherapy [102].

Since one of the factors in the development of MDR is Wnt/ $\beta$-catenin signaling pathway activation [107-109], the inhibitory effect of progesterone on this signaling pathway may also be a promising aspect in the clinical use of progestins as chemosensitizers.

\section{Conclusion}

Gestagens are used in several areas of clinical practice - obstetrics and gynecology, oncology, in ART procedures, for cachexia and anorexia in cancer patients and AIDS patients.

Discovery of mitochondrial, membrane-associated, and membrane progesterone receptors, as well as in-depth investigation of their mechanisms of action in signaling pathways, contribute to obtaining new knowledge about the ways progestins exert their pharmacological effect. New data on progesterone regulation of MDR provide the possibility of using progestins as chemosensitizers in anticancer therapy and as cardio-, neuro-, and hepatoprotectors. Data on progesterone regulation of the immune system (immunosuppressive action) may contribute to widening the range of indications for administration of progestins, particularly, for combating viral and autoimmune diseases.

The role of progesterone in the body can hardly be overestimated because this sex hormone contributes to normal development of pregnancy, the most important physiological process in biology.

Study funding. The study was supported by the grant of Russian Foundation for Basic Research No.19015-00195.

Conflict of interest. The authors have no conflict of interest to disclose.

\section{References}

1. Casado-Espada N.M., de Alarcón R., de la IglesiaLarrad J.I., Bote-Bonaechea B., Montejo Á.L. Hormonal contraceptives, female sexual dysfunction, and managing strategies: a review. J Clin Med 2019; 8(6): 908, https://doi. org/10.3390/jcm8060908.

2. Piette $P$. The history of natural progesterone, the never-ending story. Climacteric 2018; 21(4), https://doi.org/10. 1080/13697137.2018.1462792.

3. Carp H.J.A. Progestogens in luteal support. Horm Mol Biol Clin Investig 2020; 21(4): 380-384, https://doi.org/10.1515/ hmbci-2019-0067.

4. Garcia J.M., Shamliyan T.A. Off-label megestrol in patients with anorexia-cachexia syndrome associated with malignancy and its treatments. Am J Med 2018; 131(6): 623629.e1, https://doi.org/10.1016/j.amjmed.2017.12.028.

5. Kareva E.N., Bulgakova V.A., Gutorova D.S., Oleinikova O.M., Kononova I.N., Gorbunov A.A., Breusenko V.G., Fisenko V.P. Progesterone membrane receptor PGRMC1: potential drug target. Eksperimentalnaya 
i klinicheskaya farmakologiya 2020; 83(6): 19-29, https://doi. org/10.30906/0869-2092-2020-83-6-19-29.

6. Pedroza D.A., Subramani R., Lakshmanaswamy R. Classical and non-classical progesterone signaling in breast cancers. Cancers (Basel) 2020; 12(9): 2440, https://doi. org/10.3390/cancers12092440.

7. Petersen S.L., Intlekofer K.A., Moura-Conlon P.J., Brewer D.N., Del Pino Sans J., Lopez J.A. Novel progesterone receptors: neural localization and possible functions. Front Neurosci 2013; 7: 164, https://doi.org/10.3389/ fnins.2013.00164.

8. Pang Y., Dong J., Thomas P. Characterization, neurosteroid binding and brain distribution of human membrane progesterone receptors $\delta$ and $\varepsilon$ ( $\mathrm{mPR} \delta$ and $\mathrm{mPR} \varepsilon$ ) and $\mathrm{mPR} \delta$ involvement in neurosteroid inhibition of apoptosis. Endocrinology 2013; 154(1): 283-295, https://doi.org/10.1210/ en.2012-1772.

9. Ryu C.S., Klein K., Zanger U.M. Membrane associated progesterone receptors: promiscuous proteins with pleiotropic functions - focus on interactions with cytochromes P450. Front Pharmacol 2017; 8: 159, https://doi.org/10.3389/ fphar.2017.00159.

10. Thejer B.M., Adhikary P.P., Kaur A., Teakel S.L., Van Oosterum A., Seth I., Pajic M., Hannan K.M., Pavy M., Poh P., Jazayeri J.A., Zaw T., Pascovici D., Ludescher M., Pawlak M., Cassano J.C., Turnbull L., Jazayeri M., James A.C., Coorey C.P., Roberts T.L., Kinder S.J., Hannan R.D., Patrick E., Molloy M.P., New E.J., Fehm T.N., Neubauer H., Goldys E.M., Weston L.A., Cahill M.A. PGRMC1 phosphorylation affects cell shape, motility, glycolysis, mitochondrial form and function, and tumor growth. BMC Mol and Cell Biol 2020; 21(1): 24, https:// doi.org/10.1186/s12860-020-00256-3.

11. Idkowiak J., Randell T., Dhir V., Patel P., Shackleton C.H., Taylor N.F., Krone N., Arlt W. A missense mutation in the human cytochrome b5 gene causes $46, \mathrm{XY}$ disorder of sex development due to true isolated 17,20 lyase deficiency. J Clin Endocrinol Metab 2012; 97(3): E465-E475, https://doi.org/10.1210/jc.2011-2413.

12. Price T., Dai $Q$. The role of a mitochondrial progesterone receptor (PR-M) in progesterone action. Semin Reprod Med 2015; 33(3): 185-194, https://doi.org/10.1055/s-0035-1552583.

13. Ren J., Chung-Davidson Y.W., Jia L., Li W. Genomic sequence analyses of classical and non-classical lamprey progesterone receptor genes and the inference of homologous gene evolution in metazoans. BMC Evol Biol 2019; 19(1): 136, https://doi.org/10.1186/s12862-019-1463-7.

14. Africander D., Verhoog N., Hapgood J.P. Molecular mechanisms of steroid receptor-mediated actions by synthetic progestins used in HRT and contraception. Steroids 2011, 76(7): 636-652, https://doi.org/10.1016/j.steroids.2011.03.001.

15. Smetnik A.A. Contraception with drospirenone: effect on the body weight and some lipid metabolism indicators. Meditsinskiy sovet 2016; 12: 95-97, https://doi. org/10.21518/2079-701x-2016-12-95-97.

16. Fedotcheva T.A., Shimanovskiy N.L. Gestagens in the treatment of endometriosis. Problemy endokrinologii 2018; 64(1): 54-61, https://doi.org/10.14341/probl201864154-61.

17. Stepanova E.S., Makarenkova L.M., Chistyakov V.V., Fedotcheva T.A., Parshin V.A., Shimanovsky N.L. Metabolism of gestobutanoil, a novel drug of progestin group. Sovremennye tehnologii $v$ medicine 2019; 11(3): 48-54, https://doi.org/10.17691/stm2019.11.3.06.

18. Trojano G., Olivieri C., Tinelli R., Damiani G.R.,
Pellegrino A., Cicinelli E. Conservative treatment in early stage endometrial cancer: a review. Acta Biomed 2019; 90(4): 405410, https://doi.org/10.23750/abm.v90i4.7800.

19. Mitsuhashi A., Kawasaki Y., Hori M., Fujiwara T., Hanaoka H., Shozu M. Medroxyprogesterone acetate plus metformin for fertility-sparing treatment of atypical endometrial hyperplasia and endometrial carcinoma: trial protocol for a prospective, randomised, open, blinded-endpoint design, dose-response trial (FELICIA trial). BMJ Open 2020; 10(2): e035416, https://doi.org/10.1136/bmjopen-2019-035416.

20. Mitsuhashi A., Habu Y., Kobayashi T., Kawarai Y., Ishikawa H., Usui H., Shozu M. Long-term outcomes of progestin plus metformin as a fertility-sparing treatment for atypical endometrial hyperplasia and endometrial cancer patients. J Gynecol Oncol 2019; 30(6): e90, https://doi. org/10.3802/jgo.2019.30.e90.

21. Stepan J.J., Hruskova H., Kverka M. Update on menopausal hormone therapy for fracture prevention. Curr Osteoporos Rep 2019; 17(6): 465-473, https://doi.org/10.1007/ s11914-019-00549-3.

22. Ruiz-García V., López-Briz E., Carbonell-Sanchis R., Bort-Martí S., Gonzálvez-Perales J.L. Megestrol acetate for cachexia-anorexia syndrome. A systematic review. J Cachexia Sarcopenia Muscle 2018; 9(3): 444-452, https://doi. org/10.1002/jcsm.12292.

23. Tuca A., Jimenez-Fonseca P., Gascón P. Clinical evaluation and optimal management of cancer cachexia. Crit Rev Oncol Hematol 2013; 88(3): 625-636, https://doi. org/10.1016/j.critrevonc.2013.07.015.

24. Yang H.C., Liu J.C., Liu F.S. Fertility-preserving treatment of stage IA, well-differentiated endometrial carcinoma in young women with hysteroscopic resection and high-dose progesterone therapy. Taiwan J Obstet Gynecol 2019; 58(1): 90-93, https://doi.org/10.1016/j.tjog.2018.11.017.

25. Di Renzo G.C., Giardina I., Clerici G., Brillo E., Gerli S. Progesterone in normal and pathological pregnancy. Horm Mol Biol Clin Investig 2016; 27(1): 35-48, https://doi.org/10.1515/ hmbci-2016-0038.

26. Wang X., Luo Q., Bai W. Efficacy of progesterone on threatened miscarriage: difference in drug types. J Obstet Gynaecol Res 2019; 45(4): 794-802, https://doi.org/10.1111/ jog.13909.

27. Abdelhakim A.M., Abd-ElGawad M., Hussein R.S., Abbas A.M. Vaginal versus intramuscular progesterone for luteal phase support in assisted reproductive techniques: a systematic review and meta-analysis of randomized controlled trials. Gynecol Endocrinol 2020; 36(5): 389-397, https://doi.org/ 10.1080/09513590.2020.1727879.

28. Coomarasamy A., Devall A.J., Brosens J.J., Quenby S., Stephenson M.D., Sierra S., Christiansen O.B., Small R., Brewin J., Roberts T.E., Dhillon-Smith R., Harb H., Noordali H., Papadopoulou A., Eapen A., Prior M., Di Renzo G.C., Hinshaw K., Mol B.W., Lumsden M.A., Khalaf Y., Shennan A., Goddijn M., van Wely M., Al-Memar M., Bennett P., Bourne T., Rai R., Regan L., Gallos I.D. Micronized vaginal progesterone to prevent miscarriage: a critical evaluation of randomized evidence. Am J Obstet Gynecol 2020; 223(2): 167-176, https:// doi.org/10.1016/j.ajog.2019.12.006.

29. Lee H.J., Park T.C., Kim J.H., Norwitz E., Lee B. The influence of oral dydrogesterone and vaginal progesterone on threatened abortion: a systematic review and meta-analysis. Biomed Res Int 2017; 2017: 3616875, https://doi.org/10. $1155 / 2017 / 3616875$. 
30. Coomarasamy A., Devall A.J., Cheed V., Harb H., Middleton L.J., Gallos I.D., Williams H., Eapen A.K., Roberts T., Ogwulu C.C., Goranitis I., Daniels J.P., Ahmed A., BenderAtik R., Bhatia K., Bottomley C., Brewin J., Choudhary M., Crosfill F., Deb S., Duncan W.C., Ewer A., Hinshaw K., Holland T., Izzat F., Johns J., Kriedt K., Lumsden M.A., Manda P., Norman J.E., Nunes N., Overton C.E., Quenby S., Rao S., Ross J., Shahid A., Underwood M., Vaithilingam N., Watkins L., Wykes C., Horne A., Jurkovic D. A randomized trial of progesterone in women with bleeding in early pregnancy. $N$ Engl J Med 2019; 380(19): 1815-1824, https://doi. org/10.1056/nejmoa1813730.

31. Egarter C. Progestogen-only pills: which progestogen would be ideal. Horm Mol Biol Clin Investig 2020, https://doi. org/10.1515/hmbci-2019-0042.

32. Shimanovskiy N.L., Svistunov A.A., Napolov Yu.K. Novye dostizheniya $v$ gormonal'noy kontratseptsii [New achievements in hormonal contraception]. Moscow; 2013.

33. Chen M.J., Hsia J.K., Creinin M.D. Etonogestrel implant use in women primarily choosing a combined oral contraceptive pill: a proof-of-concept trial. Contraception 2018; 97(6): 533537, https://doi.org/10.1016/j.contraception.2018.02.009.

34. Floyd J.L., Beasley A.D., Swaim L.S., Turrentine M.A., Nijjar J.B. Association of immediate postpartum etonogestrel implant insertion and venous thromboembolism. Obstet Gynecol 2020; 135(6): 1275-1280, https://doi.org/10.1097/ aog.0000000000003760.

35. Louw-du Toit R., Hapgood J.P., Africander D. A direct comparison of the transcriptional activities of progestins used in contraception and menopausal hormone therapy via the mineralocorticoid receptor. Biochem Biophys Res Commun 2020; 526(2): 466-471, https://doi.org/10.1016/j. bbrc.2020.03.100.

36. Secura G.M., Allsworth J.E., Madden T., Mullersman J.L., Peipert J.F. The Contraceptive CHOICE Project: reducing barriers to long-acting reversible contraception. Am J Obstet Gynecol 2010; 203(2): 115.e1-115. e1157, https://doi.org/10.1016/j.ajog.2010.04.017.

37. Bahar Y.Z., Gold M.A. Providing long-acting reversible contraception to adolescents: a review. Clin Obstet Gynecol 2020; 63(3): 561-573, https://doi.org/10.1097/ grf.0000000000000541.

38. Festin M.P.R. Overview of modern contraception. Best Pract Res Clin Obstet Gynaecol 2020; 66: 4-14, https://doi. org/10.1016/j.bpobgyn.2020.03.004.

39. Savilova A.M., Yushina M.N., Rudimova Y.V., Khabas G.N., Chuprynin V.D., Sukhikh G.T. Characteristics of multipotent mesenchymal stromal cells isolated from human endometrium and endometriosis lesions. Bull Exp Biol Med 2016; 161(4): 610-615, https://doi.org/10.1007/s10517-0163469-0.

40. Guo H., Li J., Shen X., Cong Y., Wang Y., Wu L., Li B., Gao H., Ma M., Zhang W., Mao X., Fu Y., Lyu Q., Chai W., Kuang Y. Efficacy of different progestins in women with advanced endometriosis undergoing controlled ovarian hyperstimulation for in vitro fertilization - a single-center non-inferiority randomized controlled trial. Front Endocrinol (Lausanne) 2020; 11: 129, https://doi.org/10.3389/ fendo.2020.00129.

41. Dianat S., Fox E., Ahrens K.A., Upadhyay U.D., Zlidar V.M., Gallo M.F., Stidd R.L., Moskosky S., Dehlendorf $C$. Side effects and health benefits of depot medroxyprogesterone acetate: a systematic review. Obstet
Gynecol 2019; 133(2): 332-341, https://doi.org/10.1097/ aog. 0000000000003089 .

42. Shimanovskiy N.L., Fedotcheva T.A., Semeykin A.V., Parshin V.A., Sheina N.I., Skryabina E.G. Oral form of gestagen-containing composition for treating women with conditions of gestagen insufficiency and method for preparing it. Patent RU 2684917. 2019.

43. Sheina N.I., Parshin V.A., Fedotcheva T.A., Shimanovsky N.L. Effect of the new steroid drug gestobutanoil for hormone replacement therapy of gestagenous insufficiency on the development of fetus and offspring in experiments on rats. Toksikologiceskij vestnik 2019; 2: 28-36, https://doi. org/10.36946/0869-7922-2019-2-28-36.

44. Sheina N.I., Parshin V.A., Kolesnikova V.V., Myalina L.I., Sazonova L.P., Fedotcheva T.A., Shimanovskiy N.L. Estimation of the generative function of female rats upon intra-gastric administration of tablets of new steroid drug gestobutanoil. Khimiko-farmatsevticheskii zhurnal 2020; 54(5): 11-15, https:// doi.org/10.30906/0023-1134-2020-54-5-11-15.

45. Sheina N.I., Parshin V.A., Rybakov Yu.L., Gukasov V.M., Kostyaeva M.G., Semeykin A.V., Samoylikov R.V., Fedotcheva T.A., Shimanovskiy N.L. Evaluation of the toxicity of new progestogen gestobutanoil in experiments on rats and mice. Eksperimentalnaya i klinicheskaya farmakologiya 2018; 81(11): 18-25, https://doi.org/10.30906/0869-2092-2018-8111-18-25.

46. Petrosyan M.A., Balashova N.N., Polyanskikh L.S., Baziyan E.V., Tral' T.G., Fasakhutdinova L.Kh., Razygraev A.V., Sapronov N.S. Effect of progesterone analogs on endometrioid heterotopias in an experimental model of endometriosis. Eksperimentalnaya i klinicheskaya farmakologiya 2018; 81(7): 14-19, https://doi.org/10.30906/0869-2092-2018-81-7-14-19.

47. Lee S.Y., Kim M.K., Park H., Yoon B.S., Seong S.J., Kang J.H., Jun H.S., Park C.T. The effectiveness of levonorgestrel releasing intrauterine system in the treatment of endometrial hyperplasia in Korean women. J Gynecol Oncol 2010; 21(2): 102-105, https://doi.org/10.3802/ jgo.2010.21.2.102.

48. Lai Y.J., Chou Y.C., Lin Y.J., Yu M.H., Ou Y.C., Chu P.W., Wu C.C., Wang Y.C., Chao T.K. Pyruvate kinase M2 expression: a potential metabolic biomarker to differentiate endometrial precancer and cancer that is associated with poor outcomes in endometrial carcinoma. Int J Environ Res Public Health 2019; 16(23): 4589, https://doi.org/10.3390/ ijerph16234589.

49. Travaglino A., Raffone A., Saccone G., Mascolo M., D'Alessandro P., Arduino B., Mollo A., Insabato L., Zullo F. Nuclear expression of $\beta$-catenin in endometrial hyperplasia as marker of premalignancy. APMIS 2019; 127(11): 699-709, https://doi.org/10.1111/apm.12988.

50. Zaino R.J. Unusual patterns of endometrial carcinoma including MELF and its relation to epithelial mesenchymal transition. Int J Gynecol Pathol 2014; 33(4): 357-364, https:// doi.org/10.1097/pgp.0000000000000137.

51. Gallos I.D., Alazzam M., Clark T. Endometrial hyperplasia, management of (green-top guideline No. 67). Royal College of Obstetricians and Gynaecologists; 2016; URL: https://www.rcog.org.uk/en/guidelines-research-services/ guidelines/gtg67/.

52. Landersoe S.K., Forman J.L., Birch Petersen K., Larsen E.C., Nøhr B., Hvidman H.W., Nielsen H.S., Nyboe Andersen A. Ovarian reserve markers in women using various hormonal contraceptives. Eur J Contracept Reprod Health Care 
2020; 25(1): 65-71, https://doi.org/10.1080/13625187.2019. 1702158 .

53. Korennaya V.V., Mass E.E., Koloda Yu.A., Poletova T.N. Hyperplastic endometrial processes: the new approach to the problem. Effektivnaa farmakoterapia 2018; 3: 34-39.

54. Morice P., Leary A., Creutzberg C., Abu-Rustum N., Darai E. Endometrial cancer. Lancet 2016; 387(10023): 10941108, https://doi.org/10.1016/s0140-6736(15)00130-0.

55. Gompel A. Progesterone, progestins and the endometrium in perimenopause and in menopausal hormone therapy. Climacteric 2018; 21(4): 321-325, https://doi.org/10. 1080/13697137.2018.1446932.

56. Nechushkina V.M., Den'gina N.V., Kolomiets L.A., Kravets O.A., Morkhov K.Yu., Novikova E.G., Tyulyandina A.S., Ul'rikh E.A., Fedenko A.A., Khokhlova S.V. Practical recommendations for drug treatment of uterine body cancer and uterine sarcomas. Zlokachestvennye opukholi 2017; 7(3S2): 168-180.

57. Tamauchi S., Kajiyama H., Utsumi F., Suzuki S., Niimi K., Sakata J., Mizuno M., Shibata K., Kikkawa F. Efficacy of medroxyprogesterone acetate treatment and retreatment for atypical endometrial hyperplasia and endometrial cancer. J Obstet Gynaecol Res 2018; 44(1): 151-156, https://doi. org/10.1111/jog.13473.

58. Yamagami W., Susumu N., Makabe T., Sakai K., Nomura H., Kataoka F., Hirasawa A., Banno K., Aoki D. Is repeated high-dose medroxyprogesterone acetate (MPA) therapy permissible for patients with early stage endometrial cancer or atypical endometrial hyperplasia who desire preserving fertility? J Gynecol Oncol 2018; 29(2): e21, https:// doi.org/10.3802/jgo.2018.29.e21.

59. Kim J.J., Kurita T., Bulun S.E. Progesterone action in endometrial cancer, endometriosis, uterine fibroids, and breast cancer. Endocr Rev 2013; 34(1): 130-162, https://doi. org/10.1210/er.2012-1043.

60. Cao W., Gao W., Zheng P., Sun X., Wang L. Medroxyprogesterone acetate causes the alterations of endoplasmic reticulum related mRNAs and IncRNAs in endometrial cancer cells. BMC Med Genomics 2019; 12(1): 163, https://doi.org/10.1186/s12920-019-0601-9.

61. Urmancheeva A.F. Endometrial cancer drug therapy. Prakticeskaa onkologia 2004; 5(1): 41-51.

62. Badwe R., Hawaldar R., Parmar V., Nadkarni M., Shet T., Desai S., Gupta S., Jalali R., Vanmali V., Dikshit R., Mittra I. Single-injection depot progesterone before surgery and survival in women with operable breast cancer: a randomized controlled trial. J Clin Oncol 2011; 29(21): 2845-2851, https:// doi.org/10.1200/jco.2010.33.0738.

63. Khokhlova S.V., Den'gina N.V., Kolomiets L.A., Kravets O.A., Morkhov K.Yu., Nechushkina V.M., Novikova E.G., Tyulyandina A.S., Urmancheeva A.F. Practical guidelines for drug treatment of cervical cancer. Zlokachestvennye opukholi 2017; 7(3-S2): 158-167.

64. Ulrikh E.A., Berlev I.V., Urmancheeva A.F., Verbitskaya E.A., Mikaya N.A., Mikhailov A.V., Iliin A.B., Gamzatova Z.N., Yankevich Yu.V., Artemieva A.S., Korolkova E.N. Personalization in treatment for cervical cancer during pregnancy. Voprosy onkologii 2015; 61(3): 486-493.

65. Liu Y., Tian L.B., Yang H.Y., Zhang H.P. Effects of estradiol and progesterone on the growth of HeLa cervical cancer cells. Eur Rev Med Pharmacol Sci 2017; 21(17): 39593965.
66. Numata T., Sato-Numata K., Okada Y. TRPM7 is involved in acid-induced necrotic cell death in a manner sensitive to progesterone in human cervical cancer cells. Physiol Rep 2019; 7(13): e14157, https://doi.org/10.14814/phy2.14157.

67. Fedotcheva T.A., Sveshnikova E.D., Sheina N.I., Sokolov M.N., Kudryavtsev K.V., Fedotcheva N.I., Shimanovskiy N.L. Synthesis and cytostatic activity of new derivatives of mepregenol 17-acetate with respect to HeLa cancer cells. Khimiko-farmatsevticheskii zhurnal 2020; 54(2): 17-23, https://doi.org/10.30906/0023-1134-2020-54-2-17-23.

68. Semeikin A.V., Fedotcheva T.A., Tikhonov D.A., Kareva E.N., Shimanovskii N.L., Levina I.S., Kulikova L.E., Zavarzin I.V. Synthesis and cytostatic activity of some pregna-d'-pentaranes on Hela cell culture. Khimikofarmatsevticheskii zhurnal 2014; 48(6): 9-13.

69. Yang B.Y., Gulinazi Y., Du Y., Ning C.C., Cheng Y.L., Shan W.W., Luo X.Z., Zhang H.W., Zhu Q., Ma F.H., Liu J., Sun L., Yu M., Guan J., Chen X.J. Metformin plus megestrol acetate compared with megestrol acetate alone as fertility-sparing treatment in patients with atypical endometrial hyperplasia and well-differentiated endometrial cancer: a randomised controlled trial. BJOG 2020; 127(7): 848-857, https://doi.org/10.1111/1471-0528.16108.

70. Petchsila K., Prueksaritanond N., Insin P., Yanaranop M., Chotikawichean N. Effect of metformin for decreasing proliferative marker in women with endometrial cancer: a randomized double-blind placebo-controlled trial. Asian Pac J Cancer Prev 2020; 21(3): 733-741, https://doi. org/10.31557/APJCP.2020.21.3.733.

71. Zhao Y., Sun H., Feng M., Zhao J., Zhao X., Wan Q., Cai D. Metformin is associated with reduced cell proliferation in human endometrial cancer by inbibiting PI3K/AKT/mTOR signaling. Gynecol Endocrinol 2018; 34(5): 428-432, https:// doi.org/10.1080/09513590.2017.1409714.

72. Lheureux S., Oza A.M. Endometrial cancer-targeted therapies myth or reality? Review of current targeted treatments. Eur J Cancer 2016; 59: 99-108, https://doi. org/10.1016/j.ejca.2016.02.016.

73. Lee D.Y., Lee T.S. Associations between metabolic syndrome and gynecologic cancer. Obstet Gynecol Sci 2020; 63(3): 215-224, https://doi.org/10.5468/ogs.2020.63.3.215.

74. Horwitz K.B., Sartorius C.A. 90 years of progesterone: progesterone and progesterone receptors in breast cancer: past, present, future. J Mol Endocrinol 2020; 65(1): T49-T63, https://doi.org/10.1530/jme-20-0104.

75. Prior J.C. Progesterone for treatment of symptomatic menopausal women. Climacteric 2018; 21(4): 358-365, https:// doi.org/10.1080/13697137.2018.1472567.

76. Prior J.C. Progesterone is important for transgender women's therapy-applying evidence for the benefits of progesterone in ciswomen. J Clin Endocrinol Metab 2019; 104(4): 1181-1186, https://doi.org/10.1210/jc.2018-01777.

77. Warren M.P., Biller B.M., Shangold M.M. A new clinical option for hormone replacement therapy in women with secondary amenorrhea: effects of cyclic administration of progesterone from the sustained-release vaginal gel Crinone $(4 \%$ and $8 \%)$ on endometrial morphologic features and withdrawal bleeding. Am J Obstet Gynecol 1999; 180(1): 4248, https://doi.org/10.1016/s0002-9378(99)70147-x.

78. Farquhar C., Rombauts L., Kremer J.A., Lethaby A., Ayeleke R.O. Oral contraceptive pill, progestogen or oestrogen pretreatment for ovarian stimulation protocols for women undergoing assisted reproductive techniques. Cochrane 
Database Syst Rev 2017; 5(5): CD006109, https://doi. org/10.1002/14651858.cd006109.pub3.

79. Zolton J.R., Lindner P.G., Terry N., DeCherney A.H., Hill M.J. Gonadotropins versus oral ovarian stimulation agents for unexplained infertility: a systematic review and metaanalysis. Fertil Steril 2020; 113(2): 417-425.e1, https://doi. org/10.1016/j.fertnstert.2019.09.042.

80. Syrkasheva A.G., Petrosyan Y.A., Dolgushina N.V. Gestagens in assisted reproductive technology programs. Ginekologia 2019; 21(2): 76-79, https://doi.org/10.26442/2079 5696.2019.2.190238.

81. Bulgakova V.P., Borovikov I.O. Use of micronized natural progesterone as preparation for assisted reproductive technologies in patients with uterine infertility factor. Problemy reprodukcii 2018; 24(6): 67-75, https://doi.org/10.17116/ repro20182406167.

82. Khramtsova A.Yu., Bashmakova N.V. Global view on the problem of "thin" endometrium: solutions to the problem in assisted reproductive technology (literature review). Problemy reprodukcii 2019; 25(4): 69-76, https://doi.org/10.17116/ repro20192504169.

83. Metodicheskie rekomendatsii po opredeleniyu spetsificheskoy farmakologicheskoy aktivnosti steroidnykh gormonov i ikh antagonistov. V kn.: Rukovodstvo po provedeniyu doklinicheskikh issledovaniy lekarstvennykh sredstv [Guidelines for determining the specific pharmacological activity of steroid hormones and their antagonists. In: Guidelines for conducting preclinical studies of drugs]. Pod red. Mironova A.N. [Mironov A.N. (editor)]. Moscow: Grif i K; 2012; p. 702-711.

84. Arab H., Alharbi A.J., Oraif A., Sagr E., Al Madani H., Abduljabbar H., Bajouh O.S., Faden Y., Sabr Y. The role of progestogens in threatened and idiopathic recurrent miscarriage. Int J Womens Health 2019; 11: 589-596, https:// doi.org/10.2147/ijwh.s224159.

85. Goddard L.M., Ton A.N., Org T., Mikkola H.K.A., IruelaArispe M.L. Selective suppression of endothelial cytokine production by progesterone receptor. Vascul Pharmacol 2013; 59(1-2): 36-43, https://doi.org/10.1016/j.vph.2013.06.001.

86. VanLandingham J.W., Cekic M., Cutler S., Hoffman S.W., Stein D.G. Neurosteroids reduce inflammation after TBI through CD55 induction. Neurosci Lett 2007; 425(2): 94-98, https://doi.org/10.1016/j.neulet.2007.08.045.

87. Qin Y.Y., Zhou Y.H., Lu Y.Q., Sun F., Yang S., Harypursat V., Chen Y.K. Effectiveness of glucocorticoid therapy in patients with severe coronavirus disease 2019: protocol of a randomized controlled trial. Chin Med J (Engl) 2020; 133(9): 1080-1086, https://doi.org/10.1097/ CM9.0000000000000791.

88. Erickson T.B., Chai P.R., Boyer E.W. Chloroquine, hydroxychloroquine and COVID-19. Toxicol Commun 2020; 4(1): 40-42, https://doi.org/10.1080/24734306.2020.1757967.

89. Zhao W., Cong Y., Li H.M., Li S., Shen Y., Qi Q., Zhang Y., Li Y.Z., Tang Y.J. Challenges and potential for improving the druggability of podophyllotoxin-derived drugs in cancer chemotherapy. Nat Prod Rep 2020, https://doi. org/10.1039/d0np00041h.

90. Ogurtsov S.I., Dukhanin A.S., Levina I.S., Shimanovskiy N.L. Effect of synthetic progestogens from the group of nitrogen-containing pentarans on the activity of rat liver tyrosine aminotransferase. Eksperimentalnaya $i$ klinicheskaya farmakologiya 2015; 78(5): 47-48.

91. Fedotcheva T.A., Kruglov A.G., Teplova V.V.,
Fedotcheva N.I., Rzheznikov V.M., Shimanovskii N.L. Effect of steroid hormones on production of reactive oxygen species in mitochondria. Biophysics 2012; 57(6): 792-795, https://doi. org/10.1134/s0006350912060061.

92. Liga A.B., Ukhina T.V., Shimanovski N.L. Activity lysosomal enzymes in rat skin fibroblasts after treatment with progesterone and new gestagen ABMP. Bull Exp Biol Med 2008; 145(1): 44-46, https://doi.org/10.1007/s10517-008-0013-x.

93. Shchelkunova T.A., Morozov I.A. Molecular basis and tissue specificity of the progestin effect. Molekularnaa biologia 2015; 49(5): 728, https://doi.org/10.7868/s0026898415050158.

94. Porokhin A.P., Kudrin V.S., Klodt P.M., Narkevich V.B., Matyushin A.I., Rogovsky V.S., Rzheznikov V.M., Shimanovsky N.L. Synthetic gestagen buterol influence on monoamine metabolism in rats brain. Vestnik RGMU 2011; 2 : 72-74.

95. Fedotcheva T.A., Teplova V.V., Fedotcheva N.I. Activation of the calcium-dependent cyclosporin-sensitive mitochondrial pore by doxorubicin in combination with iron ions. Biologicheskie membrany: zhurnal membrannoy $i$ kletochnoy biologii 2018; 35(1): 79-84, https://doi.org/10.7868/ s0233475518010097.

96. Sergeyev P.V., Atroshkin K.A., Semeikin A.V., Shimanovsky N.L. Fedotcheva T.A., Sekirina M.A. Gestagen regulation of target cell proliferation activity. Vestnik Rossijskogo onkologiceskogo naucnogo centra imeni N.N. Blohina RAMN 2008; 19(1): 22-28.

97. Fedotcheva N.I., Teplova V.V., Fedotcheva T.A., Rzheznikov V.M., Shimanovskii N.L. Effect of progesterone and its synthetic analogues on the activity of mitochondrial permeability transition pore in isolated rat liver mitochondria. Biochem Pharmacol 2009; 78(8): 1060-1068, https://doi. org/10.1016/j.bcp.2009.05.028.

98. Fedotcheva T.A., Odintsova E.V., Shimanovsky N.L. Molecular mechanisms of cytostatic and chemosensitizing action of gestagens. Vestnik Rossiiskoi akademii meditsinskikh nauk 2010; 9: 42-50.

99. Chiu H.C., Li C.J., Yiang G.T., Tsai A.P., Wu M.Y. Epithelial to mesenchymal transition and cell biology of molecular regulation in endometrial carcinogenesis. J Clin Med 2019; 8(4): 439, https://doi.org/10.3390/jcm8040439.

100. van der Horst P.H., Wang Y., Vandenput I., Kühne L.C., Ewing P.C., van ljcken W.F., van der Zee M., Amant F., Burger C.W., Blok L.J. Progesterone inhibits epithelial-to-mesenchymal transition in endometrial cancer. PLoS One 2012; 7(1): e30840, https://doi.org/10.1371/journal.pone.0030840.

101. Huang X., Zhong R., He X., Deng Q., Peng X., Li J., Luo $X$. Investigations on the mechanism of progesterone in inhibiting endometrial cancer cell cycle and viability via regulation of long noncoding RNA NEAT1/microRNA-146b-5p mediated Wnt/ß-catenin signaling. IUBMB Life 2019; 71(2): 223-234, https://doi.org/10.1002/iub.1959.

102. Fedotcheva T.A., Odintsova E.V., Banin V.V., Shimanovskiy N.L. Pharmacological significance of the conjugate regulation of the multiple drug resistance system and the mitochondrial pore by gestagens. Vestnik Rossijskogo onkologiceskogo naucnogo centra imeni N.N. Blohina RAMN 2011; 22(4): 12-16.

103. Dong J., Qin Z., Zhang W.D., Cheng G., Yehuda A.G., Ashby C.R. Jr., Chen Z.S., Cheng X.D., Qin J.J. Medicinal chemistry strategies to discover P-glycoprotein inhibitors: an update. Drug Resist Updat 2020; 49: 100681, https://doi. org/10.1016/j.drup.2020.100681. 


\section{REVIEWS}

104. Bukowski K., Kciuk M., Kontek R. Mechanisms of multidrug resistance in cancer chemotherapy. Int $\mathrm{J} \mathrm{Mol} \mathrm{Sci}$ 2020; 21(9): 3233, https://doi.org/10.3390/ijms21093233.

105. Brayboy L.M., Knapik L.O., Long S., Westrick M., Wessel G.M. Ovarian hormones modulate multidrug resistance transporters in the ovary. Contracept Reprod Med 2018; 3: 26, https://doi.org/10.1186/s40834-018-0076-7.

106. Wu X., Zhang X., Sun L., Zhang H., Li L., Wang X., Li W., Su P., Hu J., Gao P., Zhou G. Progesterone negatively regulates $\mathrm{BCRP}$ in progesterone receptor-positive human breast cancer cells. Cell Physiol Biochem 2013; 32(2): 344354, https://doi.org/10.1159/000354442.

107. Yuan S., Tao F., Zhang X., Zhang Y., Sun X., Wu D. Role of $W n t / \beta$-catenin signaling in the chemoresistance modulation of colorectal cancer. Biomed Res Int 2020; 2020: 9390878, https://doi.org/10.1155/2020/9390878.

108. Mehdinejadiani S., Amidi F., Mehdizadeh M., Barati M., Pazhohan A., Alyasin A., Mehdinejadiani K., Sobhani A. Effects of letrozole and clomiphene citrate on Wnt signaling pathway in endometrium of polycystic ovarian syndrome and healthy women. Biol Reprod 2019; 100(3): 641648, https://doi.org/10.1093/biolre/ioy187.

109. Medina M.A., Oza G., Sharma A., Arriaga L.G., Hernández Hernández J.M., Rotello V.M., Ramirez J.T. Triple-negative breast cancer: a review of conventional and advanced therapeutic strategies. Int J Environ Res Public Health 2020; 17(6): 2078, https://doi.org/10.3390/ ijerph17062078. 